\title{
Structure and forcing of the overflow at the Storfjorden sill and its connection to the Arctic coastal polynya in Storfjorden
}

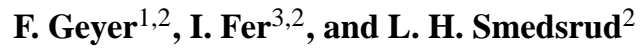 \\ ${ }^{1}$ Nansen Environmental and Remote Sensing Center, Thormølensgate 47, 5006 Bergen, Norway \\ ${ }^{2}$ Bjerknes Center for Climate Research, Allégaten 55, 5007 Bergen, Norway \\ ${ }^{3}$ Geophysical Institute, University of Bergen, Allégaten 70, 5007 Bergen, Norway
}

Received: 26 November 2009 - Published in Ocean Sci. Discuss.: 5 January 2010

Revised: 18 March 2010 - Accepted: 18 March 2010 - Published: 22 March 2010

\begin{abstract}
Storfjorden (Svalbard) is a sill-fjord with an active polynya and exemplifies the dense water formation process over the Arctic shelves. Here we report on our simulations of Storfjorden covering the freezing season of 1999-2000 using an eddy-permitting 3-D ocean circulation model with a fully coupled dynamic and thermodynamic sea-ice model. The model results in the polynya region and of the dense water plume flowing over the sill crest are compared to observations. The connections of the overflow at the sill to the dense water production at the polynya and to the local wind forcing are investigated. Both the overflow and the polynya dynamics are found to be sensitive to wind forcing. In response to freezing and brine rejection over the polynya, the buoyancy forcing initiates an abrupt positive density anomaly. While the ocean integrates the buoyancy forcing over several polynya events (about 25 days), the wind forcing dominates the overflow response at the sill at weather scale. In the model, the density excess is diluted in the basin and leads to a gradual build-up of dense water behind the sill. The overflow transport is typically inferred from observations using a single current profiler at the sill crest. Despite the significant variability of the plume width, we show that a constant overflow width of $15 \mathrm{~km}$ produces realistic estimates of the overflow volume transport. Another difficulty in monitoring the overflow is measuring the plume thickness in the absence of hydrographic profiles. Volume flux estimates assuming a constant plume width and the thickness inferred from velocity profiles explain $58 \%$ of the modelled overflow volume flux variance and agrees to within $10 \%$ when averaged over the overflow season.
\end{abstract}

\section{Correspondence to: F. Geyer} (florian.geyer@nersc.no)

\section{Introduction}

The continental shelves of the Arctic Ocean are widest in the world oceans and constitute the main site for water mass transformations and dense water formation in the Arctic Ocean (Aagaard et al., 1985; Bauch et al., 1995). Wind forcing is a crucial element for the chain of events including the preconditioning, the dense water production over shelves and the export of the dense water through shelf-basin interactions. Prevailing offshore winds can maintain ice-free areas in winter (coastal polynyas). Strong heat exchange in coastal polynyas leads to ice freezing, brine-drainage and formation of dense, brine-enriched shelf water (BSW). BSW contributes to the cold halocline (Aagaard et al., 1981; Winsor and Björk, 2000), to the intermediate and deep layers (Rudels and Quadfasel, 1991), and influences the overall heat and salt budget of the deep basins (Aagaard et al., 1985; Schauer, 1995). In semi-enclosed basins, wind forcing can flush the polynya-origin dense water and influence its spreading over shelves. Prior to the freezing period, wind driven upwelling of saline Atlantic origin water onto shelves can lead to denser BSW; whereas accumulation of surface melt water can hinder dense water production regardless of significant ice production.

In Storfjorden, a semi-enclosed basin in Svalbard Archipelago (Fig. 1), an active polynya recurs annually. BSW gradually fills the fjord to the sill crest $(115 \mathrm{~m})$ and initiates a gravity driven overflow (Schauer, 1995; Fer et al., 2003, 2004; Skogseth et al., 2005a). The overflow is dense enough to penetrate below the Atlantic Water in the region, and has been observed in the deep Fram Strait as a thin layer of warm, and high salinity water (Quadfasel et al., 1988). Water mass transformation in the Storfjorden polynya, mechanisms by which the basin is ventilated, and the overflow

Published by Copernicus Publications on behalf of the European Geosciences Union. 


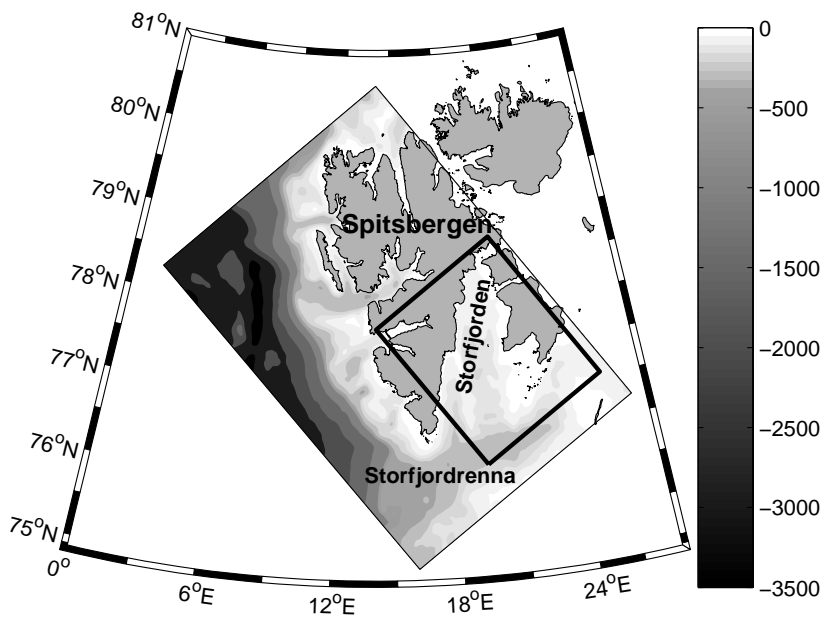

Fig. 1. Map of Storfjorden and the Svalbard archipelago. The ROMS model domain covers the filled area with a resolution of $2 \mathrm{~km}$, the smaller frame shows the extent of the model results presented in this manuscript.

structure exemplify the shelf processes in the Arctic Ocean. Using a time-dependent polynya model, Winsor and Björk (2000) estimate a total dense water production of $0.7-1.2 \mathrm{~Sv}$ $\left(1 \mathrm{~Sv}=10^{6} \mathrm{~m}^{3} \mathrm{~s}^{-1}\right)$ in the Arctic coastal polynyas. Volume transport of the Storfjorden overflow inferred from observations (Schauer, 1995; Geyer et al. 2009) amounts to 3 to $6 \%$ of the total dense water production, suggesting that the contribution of the Storfjorden polynya is significant. The reader is referred to Skogseth et al. (2005b) for hydrographic characteristics and water mass transformations in Storfjorden, to Skogseth et al. (2007) for the meso-scale surface circulation in Storfjorden and to Skogseth et al. (2008) for recent observations of the polynya processes and the polynya-overflow link.

The first numerical model for the Storfjorden region employed a hydrostatic, reduced gravity plume model using a stagnant ambient water ("1 1/2 layer model") and bulk entrainment parameterization (Jungclaus et al., 1995). Fer and Ådlandsvik (2008) conducted a high resolution 3-D idealized model study of the descent and mixing of the overflow plume in the absence of tidal and wind forcing. A typical annual cycle of the dense water production, corresponding to a moderate ice production year, was artificially introduced as buoyancy forcing in the basin north of the Storfjorden sill. Both models employed an idealized ambient stratification with horizontal isopycnals in the entire domain and concentrated on the pathway of the overflow, its descent and evolving water mass properties due to mixing. Skogseth et al. (2008) studied the fate of the polynya derived water within the Storfjorden basin (i.e., upstream of the sill) in an idealized model setting. The regional ocean model experiment presented here, including a fully coupled dynamic and thermodynamic sea-ice model, is the most realistic simulation of the dense water production and circulation in the Storfjorden region to date. Results on the ice production in the polynya obtained from the present simulation are reported in Smedsrud et al. (2006). Here, we present analysis of the model results concentrating on the description of the overflow at the Storfjorden sill and its variability due to wind forcing. In addition, the connection between the dense water source at the Storfjorden polynya and the overflow at the sill is explored. This analysis can be compared to and supplements the recent analysis of current profile observations at the Storfjorden sill (Geyer et al., 2009).

The model and the model set-up used in this study are described in detail in Smedsrud et al. (2006) and are summarized in Sect. 2 for completeness. A description of the annual cycle of ice formation, polynya events, the mean picture of the overflow at the sill and the spatial structure connected to the overflow variability are presented in Sect. 3. Subsequently, the results are discussed in Sect. 4 with particular attention to wind forcing and the overflow width at the sill, followed by our conclusions in Sect. 5 .

\section{Model and model set-up}

The Regional Ocean Modeling System (ROMS, Shchepetkin and Williams, 2005) including a fully coupled dynamic and thermodynamic sea-ice sub-model is set up as described in Smedsrud et al. (2006). The ROMS model is based on the primitive Boussinesq equations and employs a terrainfollowing coordinate system in the vertical (Song and Haidvogel, 1994) and general orthogonal curvilinear coordinates in the horizontal. The sea-ice model uses elastic-viscousplastic ice dynamics (Hunke and Dukowicz, 1997; Hunke, 2001) and two ice layers and one snow layer for thermodynamic calculations following Mellor and Kantha (1989) and Häkkinen and Mellor (1992). The model is split-mode explicit and the time-step is $200 \mathrm{~s}$, with an external mode time-step of $5 \mathrm{~s}$. As a turbulence closure, the generic length scale scheme (Warner et al., 2005) is used for subgrid-scale mixing of mass and momentum, with the two-equation $\mathrm{k}-\mathrm{kl}$ model parameters. The $\mathrm{k}-\mathrm{kl}$ model is a modified form of the Mellor-Yamada 2.5 closure (Mellor and Yamada, 1982). This scheme produced credible results in coastal applications where tidal mixing is important (Warner and Geyer, 2005) and performed well in an ice-ocean interaction process study in the Barents Sea using ROMS and the coupled ice model (Budgell, 2005). The model diffusivity profiles from an idealized ROMS simulation of the Storfjorden overflow compared favorably to those inferred from direct turbulence measurements (Fer and Ådlandsvik, 2008), giving further confidence on the skill of the k-kl scheme.

The ROMS model is used in a three-stage one-way nesting configuration (Budgell, 2005). A basin-scale model for the North Atlantic and Arctic Ocean was initiated in 1948, and forced daily with surface fluxes obtained from the US 
National Centers for Environmental Prediction (NCEP)/US National Center for Atmospheric Research (NCAR) reanalysis (Kalnay et al., 1996). The surface forcing was corrected for the high-resolution model ice concentration as described in Budgell (2005). Fields of wind stress, sensible and latent heat fluxes, solar and long-wave radiation, and precipitation were used for forcing the model.

The intermediate-scale model (average grid size of $9.3 \mathrm{~km}$ ) covered the Barents and Kara Seas and was run for 1990 2002, initiated with 1990 fields from the large-scale fields. This intermediate model provided the initial and boundary conditions for the 2-km horizontal resolution Storfjorden model run. The model was run for the duration of one year, starting with ice-free conditions in August 1999. The nesting steps are performed using an open boundary flow relaxation scheme (Engedahl, 1995) for both ocean and ice variables. Tides are not included in the present simulation.

The fine-scale, 2-km resolution, domain is shown in Fig. 1. The analysis in this study concentrates on the area shown in Fig. 2. The model domain is obtained by a rotated polar stereographic map projection. The bathymetry is interpolated from the 2' global dataset of the US National Geophysical Data Center (2001 version; http://www.ngdc.noaa. gov/mgg/fliers/06mgg01.html). The land mask is modified manually to fit the global self-consistent, hierarchical, highresolution shoreline database (GSHHS) coastline (Wessel and Smith, 1996). The bathymetry is smoothed by a secondorder Shapiro filter, in order to minimize pressure gradient errors associated with abrupt topography changes. The smoothing was repeated applied until the slope parameter of Beckman and Haidvogel (1993) was less than 0.25. In total 30 vertical levels are used, with a finer resolution near the surface and the bottom.

\section{Results}

\subsection{Annual cycle of ice formation and polynya events}

The modeled annual cycle of ice growth and decay in Storfjorden started (1 August 1999) and ended (31 July 2000) with open water conditions (Smedsrud et al., 2006). Daily NCEP forcing is in good agreement with observations from the Storfjorden area (Smedsrud et al., 2006; Skogseth et al., 2009). The wind direction, however, is likely biased westward as the coarse horizontal resolution of the NCEP forcing $(250 \mathrm{~km})$ does not resolve the Svalbard Archipelago well (Skogseth et al., 2007). This predominant wind direction opens the Storfjorden polynya westward, away from Edgeøya during strong wind episodes. The existing satellite images, on the other hand, indicate that the polynya opens southward (Skogseth et al., 2005a).

In mid-November, bands of ice form along Edgeøya, and sea surface temperatures fall below $0{ }^{\circ} \mathrm{C}$ in Storfjorden. During December the ice cover spreads over the fjord, reach-

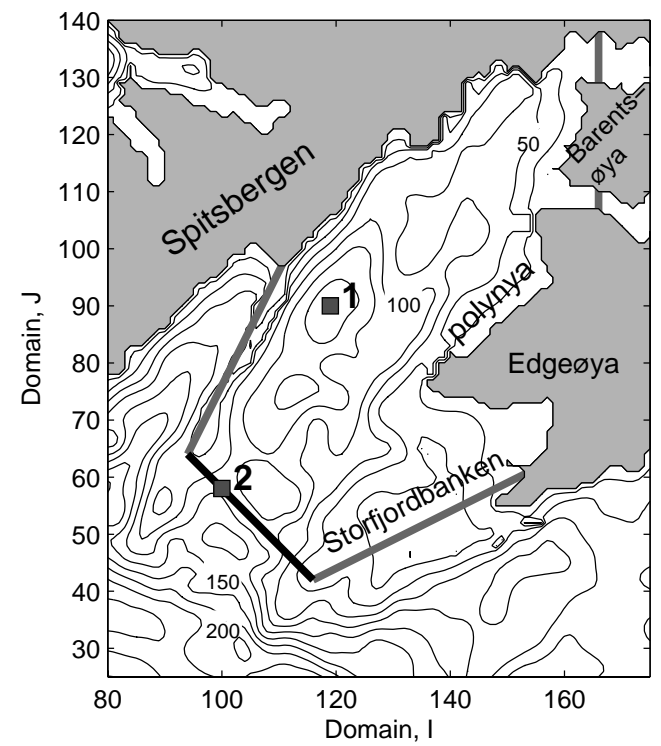

Fig. 2. Storfjorden with stations 1-2 (squares), thick lines delimit the extent of the Storfjorden basin. The black thick line is the Storfjorden sill. Station 2 is positioned at the site where the main overflow occurs across the sill. Isobaths are drawn at $25 \mathrm{~m}$ intervals. The center of the polynya area close to Edgeøya is indicated.

ing an ice concentration of around 70\%. South of Storfjorden, sea ice enters into the model domain from the Barents Sea. This ice partly accumulates on the western side of Storfjorden, increasing the sea-ice concentrations, and partly flows around the southern tip of Spitsbergen and melts in the warmer surface waters of the West Spitsbergen Current (Smedsrud et al., 2006).

During winter (January-April), sea-ice concentration in Storfjorden changes quite rapidly in response to wind forcing. During several events, the sea-ice velocity is directed away from land, opening a large polynya. We identify the polynya as grids with a mean ice thickness less than $0.3 \mathrm{~m}$, which is the transition between young and first-year ice (WMO, 1970), consistent with Smedsrud et al. (2006). Ice concentration alone is not a good criterion for identifying the polynya in a high-resolution model, because open-water areas in the model quickly freeze over with thin solid ice. In nature, this ice forms as free-floating small frazil crystals that are packed by the wind toward the leeward side of the polynya. The polynya area averaged from December to April is $2145 \mathrm{~km}^{2}$, covering $16.5 \%$ of Storfjorden area. For comparison, average polynya area inferred from a wind-driven polynya width model constrained by satellite images, wind data and surface hydrography observations, is $26.9 \%$ for the freezing period in 2000, and varies between $14-34 \%$ for the freezing seasons of 1998 to 2002 (Skogseth et al., 2005a). Polynya activity will also be influenced by tides which are not represented in this simulation. Especially close to Freemansundet north of Edgeøya the tidal currents are strong, 
however, the contribution to polynya opening and brine production is estimated to be negligible (Ersdal, 2009). Using a modified version of the polynya model of Skogseth et al. (2005a) to include tidal forcing, Ersdal (2009) reports only $2.7 \%$ increase in ice production when averaged between 1997 and 2002.

The flux of brine from the ice freezing produces the BSW, and is directly proportional to the sea-ice growth. For the BSW downflow, the polynya events set the location and timing of the strongest brine release. The largest polynya areas occur during the early winter ice formation in December and January and the northern fjord water gradually increases in salinity. During the polynya events in February-April the brine release occurs within 10-20 km offshore of Edgeøya (area indicated in Fig. 2). Following the initial freeze up, the main polynya events occur on 6-9 and 25-27 February and 22-24 March in this simulation (see Fig. 11, introduced later). Events with relatively shorter duration follow in April, before the ice formation and salt release cease in May.

\subsection{Overflow at the Storfjorden sill}

The polynya-derived water sinks to the deep pools in Storfjorden and gradually fills the basin to the sill level. Further ice formation and BSW production lead to a dense plume of BSW flowing over the sill crest. The volume transport and the density excess of the overflow are crucial in determining the depth the plume sinks down the continental slope west of Spitsbergen. Recently, the overflow has been monitored by measuring current profiles and the near-bottom temperature at the crest of the sill. The current profiles are collected using a $300 \mathrm{kHz}$ uplooking acoustic Doppler current profiler (ADCP) moored in a bottom frame. When sampled at 4-m vertical bins, the ADCP had a typical vertical range of $100 \mathrm{~m}$ which varied seasonally depending on the scatterers in the water column. Observations covering the period 2003 to 2007 are reported in Geyer et al. (2009). From the ROMS model data, we extract time series at the location corresponding to the mooring position (station 2, Fig. 2) and evaluate the skill of the simulation. To be consistent with the observation-based analysis, we define the overflow season as the period between the first and the last instance of BSW flowing across the sill, using the standard specifications for BSW ( $T<-1.5^{\circ} \mathrm{C}$ and $S>34.8$, Loeng, 1991). The modeled overflow season lasted from 6 January to 26 July 2000. This duration of 202 days, or about $55 \%$ of the year, slightly longer than the season length of 46-53\% inferred from the ADCP measuremets.

The magnitude and seasonal cycle of the overflow for the modeled year 1999-2000 at the sill (Fig. 3) are comparable to the observations (Geyer et al., 2009). The strongest out-fjord current is observed early in the season and then declines gradually, reminiscent of the mean seasonal overflow cycle established from 4 years of observations (Geyer et al., 2009). The mean seasonal modeled overflow flux is $0.07 \mathrm{~Sv}$

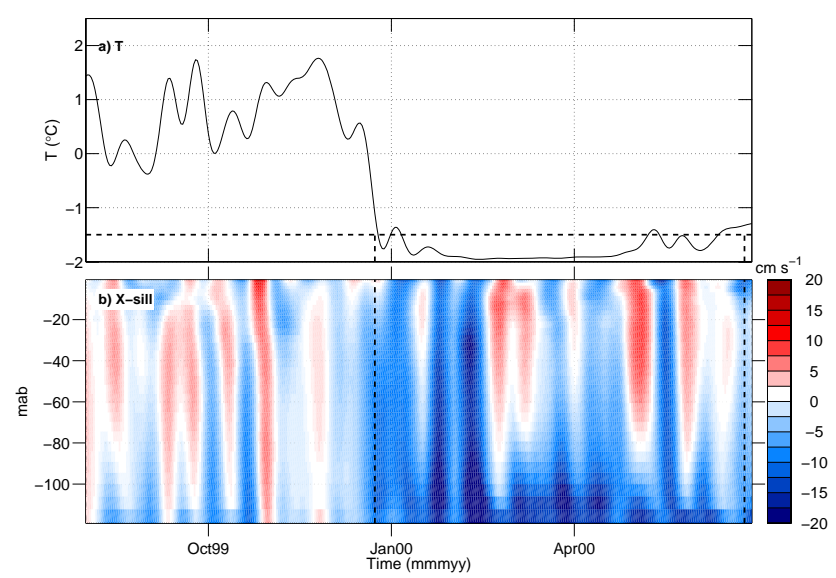

Fig. 3. Time series of (a) bottom temperature and (b) cross-sill component of the velocity (negative values out of the fjord) at station 2 . 15-day low-passed data are shown. Vertical dashed lines mark the start and end of the overflow season.

( $0.04 \mathrm{~Sv}$, annual average), larger than the ADCP-inferred annual average between $0.022-0.034 \mathrm{~Sv}$. Strong and persistent cross-sill flow directed out of the fjord is associated with cold bottom temperatures, but becomes intermittent with increasing temperatures.

During the period before the onset of the overflow season, relatively high bottom temperature and cross-sill current covary, reflecting the south-north horizontal temperature gradient across the sill. Skogseth et al. (2005b) describe this regions as the "exchange zone" between Storfjorden and Storfjordrenna.

The correspondence between the bottom temperatures and the cross-sill current profiles compares well with the observations (compare Fig. 4 with Fig. 4 of Geyer et al. (2009)). For the strongest bottom outflow, the bottom temperature is close to the freezing point, while for the inflow, temperature is above $1{ }^{\circ} \mathrm{C}$ on average. The most frequent bottom speeds are between 5 and $15 \mathrm{~cm} \mathrm{~s}^{-1}$ and directed out of the fjord. Overlain on a background outfjord flow in the entire water column is a bottom-intensified outflow. A reversal of the surface current is observed only for the strongest inflow ensembles.

The average distribution of temperature and currents along the sill section, averaged over the overflow season, is shown in Fig. 5. BSW, which forms the cold overflow from Storfjorden, is concentrated mainly on the western side of the sill where it hugs the western slope and forms a $15-20 \mathrm{~m}$ thick layer on average. Along the bottom a thinner layer of about $5 \mathrm{~m}$ thickness also stretches further east. Flow directed out of the fjord is concentrated on the western half of the sill, intensified close to the bottom associated with the BSW plume. The inflow over the eastern part of the sill is primarily connected to the modified Atlantic Water. The BSW is mainly identified by temperature since the simulated salinity over 


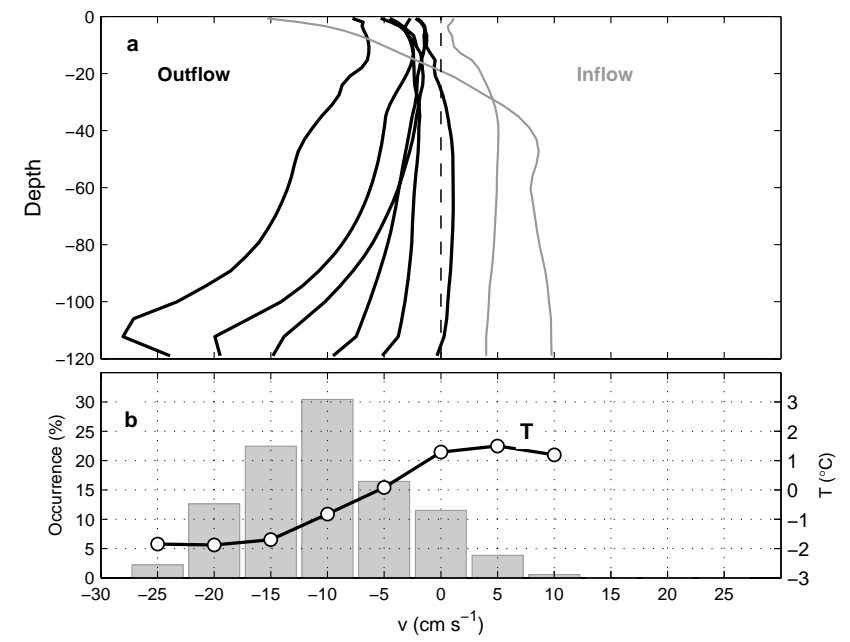

Fig. 4. (a) Average current for the cross-sill component of the velocity grouped according to the bottom current in $5 \mathrm{~cm} \mathrm{~s}^{-1}$ increments. Black (gray) traces mark outflow (inflow). (b) Histogram of northward bottom current (vertical bars) and the corresponding average bottom temperature for each velocity bin (circles).

the sill crest $S>34.8$ throughout the overflow season, biased high (see discussion in Sect. 4.2).

\subsection{Circulation in Storfjorden}

The mean surface circulation is consistent with observations (Skogseth et al., 2005b) and a previous model study (Skogseth et al., 2007). The dominant pattern in the Storfjorden basin is a cyclonic surface circulation (Fig. 6), with the main inflow over the eastern half of the sill and across Storfjordbanken, the shallow bank between the sill and Edgeøya. Inflow also occurs through the narrow Freemansundet north of Edgeøya. Surface outflow from the basin is over the western half of the sill and the adjacent ridge stretching northwards toward Spitsbergen.

Deviations from the mean surface circulation and the average distribution of flow across the sill are calculated for strong overflow cases. The average over times with the strongest overflow identified with bottom cross-sill velocities $u_{\text {out }}>20 \mathrm{~cm} \mathrm{~s}^{-1}$ (directed out of the fjord) corresponds to the following flow changes: the outflow leaning on the western slope of the sill is strengthened overall, with an intensification toward the bottom (Fig. 7a). There is a corresponding increase in the inflow strength, both over the middle part of the sill and toward the eastern flank, particularly in the upper $30 \mathrm{~m}$, and through Freemansundet between Edgeøya and Barentsøya. The surface inflow extents further across Storfjordbanken east of the sill (Fig. 7b). The increase in the surface inflow is not balanced by a corresponding increase in the surface outflow over the ridge northwest of the sill.

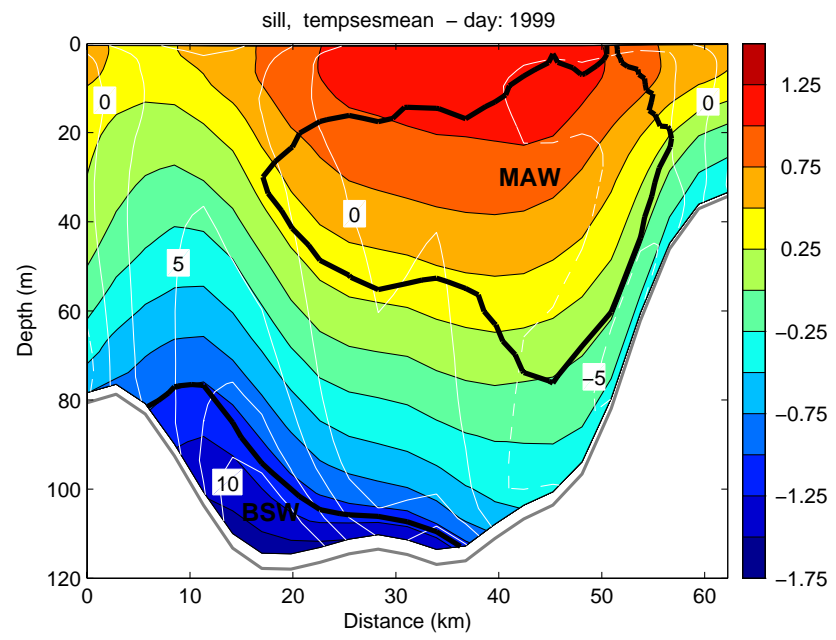

Fig. 5. Along-sill section of mean temperature (color-coded) and cross-sill velocity (white contours) for the overflow season. Contour lines are drawn in $2.5 \mathrm{~cm} \mathrm{~s}^{-1}$ increments. Solid lines denote flow directed out of the fjord, dashed lines denote flow into the fjord. Thick black lines delimit the average extent of brine-enriched shelf water (BSW) and modified atlantic water (MAW).

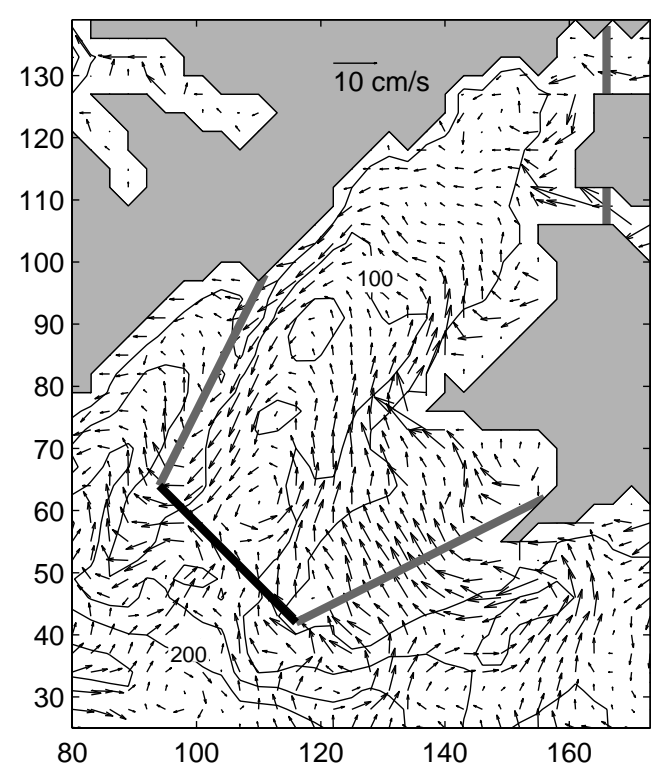

Fig. 6. Mean surface circulation in Storfjorden. Isobaths are drawn at $50 \mathrm{~m}$ intervals. Thick lines delineate the Storfjorden basin. The thick black line marks the position of the sill.

\section{Discussion}

\subsection{Wind forcing of the overflow}

Geyer et al. (2009) observed significant coherency between the wind forcing and the dense overflow at the Storfjorden sill for periods longer than 4 days and postulated a winddriven surface flow into the fjord and a return flow at depth 

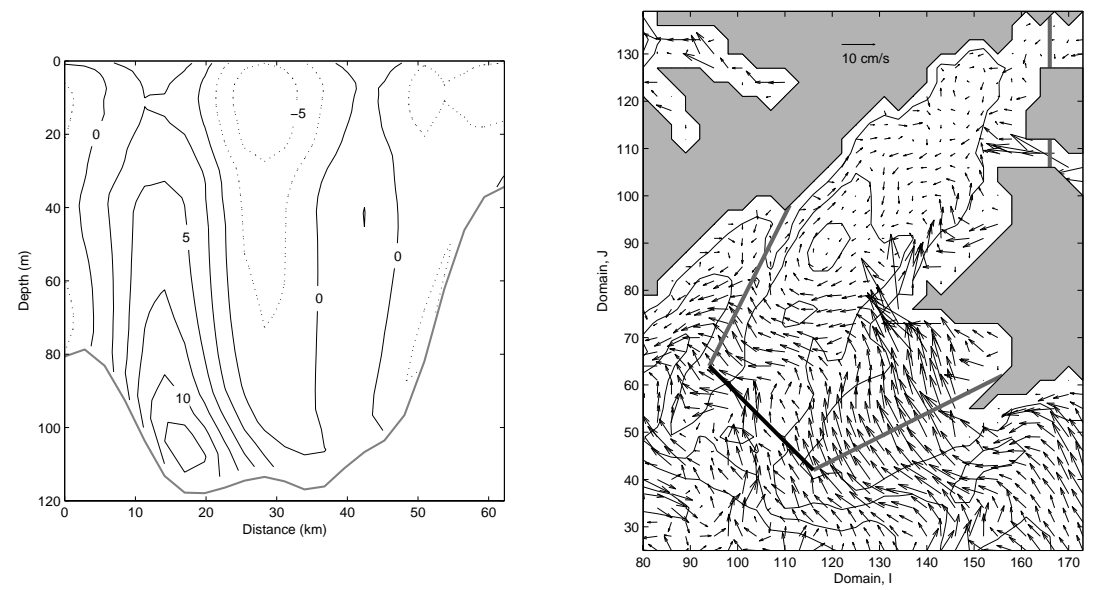

Fig. 7. Left panel: difference from mean cross-sill velocity for cases of strong outflow (cross-sill velocity $u_{\text {out }}>20 \mathrm{~cm} \mathrm{~s}^{-1}$ ). Contour lines are drawn in $2.5 \mathrm{~cm} \mathrm{~s}^{-1}$ increments. Solid lines denote flow directed out of the fjord and zero flow, dotted lines denote flow into the fjord. Right panel: difference from mean surface circulation in Storfjorden for cases of strong outflow. Isobaths are drawn at $50 \mathrm{~m}$ intervals. Thick lines delineate the Storfjorden basin. The thick black line marks the position of the sill.

as the connecting mechanism. Surface inflow is expected due to Ekman transport in response to wind stress, typically due to winds directed from $45-135^{\circ} \mathrm{T}$. We detect the times of wind from east-northeast $\left(45-90^{\circ} \mathrm{T}\right)$ and from east-southeast $\left(90-135^{\circ} \mathrm{T}\right)$, and calculated the corresponding ensemble averages. Deviations from the mean circulation are shown in Figs. 8-9. Average surface inflow is enhanced for both eastnortheasterlies (Fig. 8) and east-southeasterlies (Fig. 9). The patterns of the two different ensembles, however, vary. The wind from east-southeast transports water infjord across the entire southern boundary (Fig. 9), while the wind from eastnortheast mainly leads to an increased inflow over the bank east of the sill (Fig. 8). East-northeasterly winds also open the Storfjorden polynya west of Edgeøya (see e.g., Fig. 2 in Smedsrud et al., 2006). The connection of polynya events and overflow is discussed in Sect. 4.2.

The east-northeasterly winds are associated with an increased dense overflow (Fig. 8a). East-southeasterly winds correspond to enhanced outflow mainly at intermediate depths and the weakening of the warm inflow over the eastern part of the sill (Fig. 9a). East-northeasterlies push the surface water in Storfjorden westward against the east coast of Spitsbergen. The resulting pileup of water against the coast is the driving force for the southward return flow at depth. This surface response to wind forcing was also observed in a regional model study of the region using fine-scale wind forcing in the absence of ice (Skogseth et al., 2007).

Geyer et al. (2009) suggested that infjord surface Ekman flux had skill to predict overflow strength and variability. The flow distribution over the sill crest for the east-northeasterly winds (Fig. 8a), albeit weaker, closely resembles the distribution for the strongest overflow incidences (Sect. 3; Fig. 7). For the analysis of the model results, the net surface Ekman fluxes in and out of the fjord are calculated from the surface wind stress $\tau$

$$
F_{E, x}=\frac{\tau_{y}}{f \rho_{W}} ; F_{E, y}=-\frac{\tau_{x}}{f \rho_{W}}
$$

integrated across the boundaries of Storfjorden as indicated in Fig. 2. Here $f=1.42 \cdot 10^{-4} \mathrm{~s}^{-1}$ is the Coriolis parameter and $\rho_{W}=1027 \mathrm{~kg} \mathrm{~m}^{-3}$ is the density of sea water. The resulting net surface Ekman flux into the fjord is typically strong during the freezing period and is significantly weaker during summer, comparable to the overflow cycle (Fig. 10). During the freezing season large overflow flux is associated with large values of $F_{E}$, however, the opposite is not true. For instance, in early January significant $F_{E}$ has no discernible overflow flux, as very limited dense water is present in the fjord this early in the freezing season. We therefore conclude that while the net surface Ekman flux into the fjord can give a good indication of the overflow volume flux and its variability, caution is needed in interpreting the Ekman inflow and the bottom outflow response, as they are not directly equivalent. This conclusion is also supported by the qualitatively different response of fjord circulation and dense overflow to wind forcing by, respectively, east-southeasterly and east-northeasterly winds (Figs. 8-9).

\subsection{Polynya events and the overflow}

The two main influences on the Storfjorden overflow on time scales longer than the tidal frequencies are the buoyancy forcing from the dense water source at the Storfjorden polynya and the wind forcing in and around Storfjorden. Using hydrographic measurements in April 2006, during a supercooling event of polynya activity, Skogseth et al. (2008) trace the high salinity signal and detect it flow past the sill 

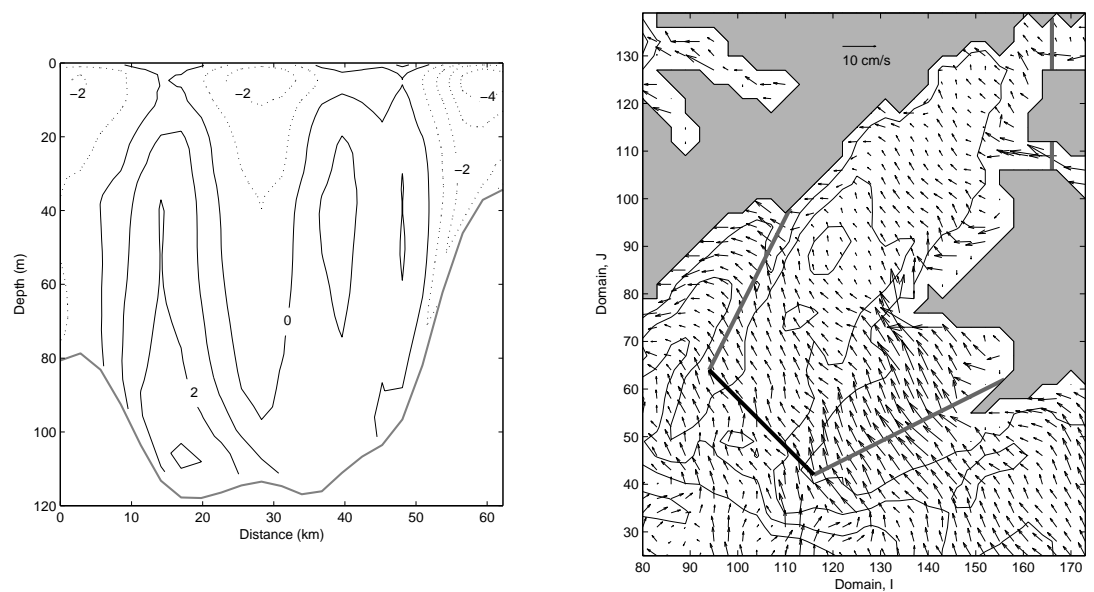

Fig. 8. Left panel: difference from mean cross-sill velocity for times of east-northeasterly winds $\left(45-90^{\circ} \mathrm{T}, 86\right.$ of 365 days). Contour lines are drawn in $1 \mathrm{~cm} \mathrm{~s}^{-1}$ increments. Solid lines denote flow directed out of the fjord and zero flow, dotted lines denote flow into the fjord. Right panel: difference from mean surface circulation in Storfjorden for times of easterly to northeasterly winds. Isobaths are drawn at $50 \mathrm{~m}$ intervals. Thick lines delineate the Storfjorden basin. The thick black line marks the position of the sill.
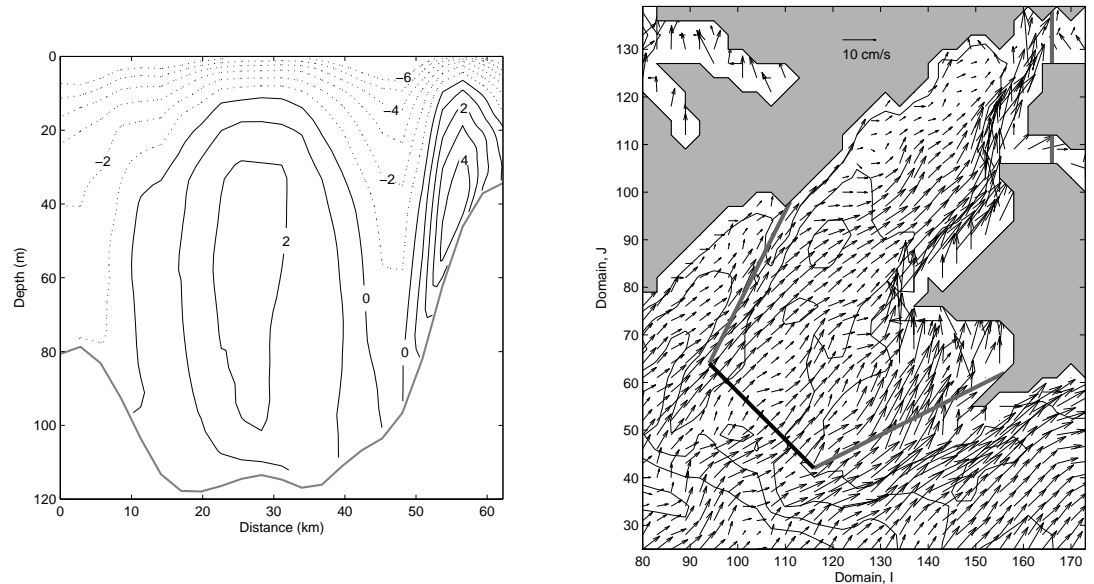

Fig. 9. Left panel: difference from mean cross-sill velocity for times of east-southeasterly winds (90-135 ${ }^{\circ} \mathrm{T}, 64$ of 365 days). Contour lines are drawn in $1 \mathrm{~cm} \mathrm{~s}^{-1}$ increments. Solid lines denote flow directed out of the fjord and zero flow, dotted lines denote flow into the fjord. Right panel: difference from mean surface circulation in Storfjorden for times of southeasterly to easterly winds. Isobaths are drawn at $50 \mathrm{~m}$ intervals. Thick lines delineate the Storfjorden basin. The thick black line marks the position of the sill.

crest 12 to 18 days after the polynya event. This time lag, also consistent with a conservative analytical estimate, compares with the filling time of the basin to the sill level from the start of freezing period. Once the interface has reached the sill level, subsequent events with high salinity pulse are estimated to reach the sill in 1 to 3 days (Skogseth et al., 2008). The ROMS model results do not support a direct polynya-overflow link with a 1-3 days time delay. It is instead dominated by an immediate (one day or less) overflow response to surface winds from east to northeast directions (Fig. 11c).
All seven major polynya events during the freezing season in 2000 can be connected to strong easterly wind events (Fig. 11). The polynya opens (gradually increasing polynya area, $\left.A_{P}\right)$, responding immediately to wind forcing (Fig. 11a). The polynya closes $\left(A_{P}\right.$ reduces due to freezing and ice formation) relatively slowly following an opening event. The closing of the polynya occurs a few days to two weeks after the wind forcing ceases. As the ice freezes in the closing polynya, salinity in the polynya region increases (Fig. 11b). Once the polynya has reached freezing temperature, all polynya events lead to ice formation and brine rejection visible as local salinity maxima in the central polynya area (Fig. 11b). 


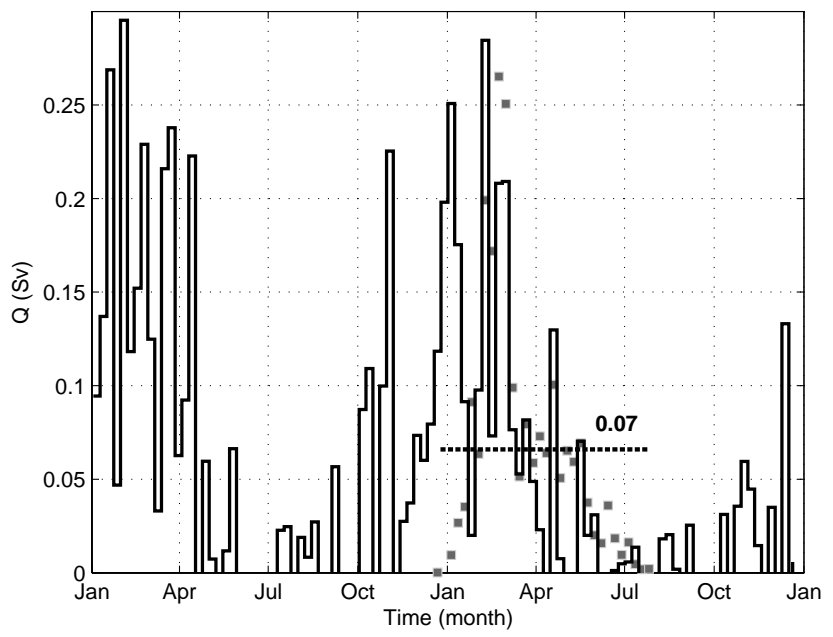

Fig. 10. Time series of weekly net surface Ekman flux $F_{E}$ into the fjord (black line) in 1999-2000 compared with the overflow volume flux $Q$ at the sill (squares). Dashed line denotes the mean value of $Q$, in $\mathrm{Sv}$, for the overflow season.

Modeled salinities are too high due to an overestimation of the import of Atlantic Water into the Barents Sea in the intermediate-scale model of the Barents and Kara Seas used in nesting (Budgell, 2005). Relatively saline water entering the polynya region then leads to BSW of high salinity. For comparison, values of maximum salinity observed in the deepest pool of the basin (hence after being diluted from the polynya to the mid-basin) vary between about 34.7 to 35.83 (Skogseth et al., 2005a) with the largest value recorded in April 2002 (Anderson et al., 2004).

Salinity maxima typically occurs 5 to 12 days following the maxima in $A_{P}$. The salinity signal of polynya events gets diluted in the basin (Fig. 11b) and it is not possible to trace a significantly high salinity pulse from the polynya to the sill. The result of polynya events is a gradual increase in salinity and density in the basin. Bottom salinity at the sill crest closely follows the salinity at the sill level in the basin but with greater variability (Fig. 11b), possibly due to episodic wind-induced overflow events carrying water from below the sill depth. Some signal propagation from the polynya can of course not be excluded, but the salinity variations at the sill adhere much closer to the wind-driven velocity variations at the sill than to salinity variations upstream. Salinity variations as a cause for the velocity variations at the sill can be excluded as the salinity maxima at the sill are occurring with 1-2 days time lag to the overflow transport maxima.

Lagged-correlation analysis yield $r^{2}=0.78$ at 25 days lag between the polynya area and the overflow at the sill. Maximum correlation with the wind stress, on the other hand, is at one day lag (wind leading), 0.55 using wind stress and 0.69 using the favorable wind stress component from $67.5^{\circ} \mathrm{T}$. All the stated values are significant at $95 \%$ confidence. The ocean thus integrates the polynya forcing over

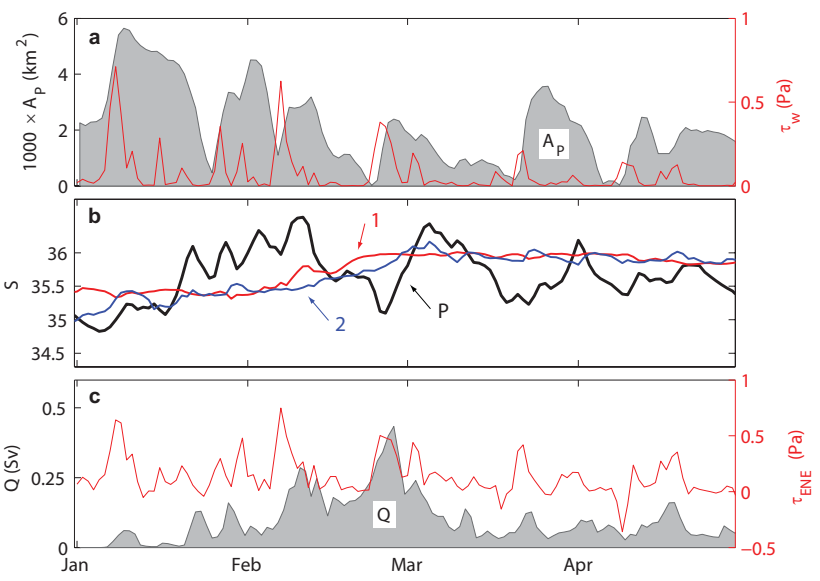

Fig. 11. Comparison of daily time series for (a)polynya area $A_{P}$ (gray shading) and wind stress $\tau_{w}$ (red) (b) bottom salinity $S$ averaged in the polynya area close to Edgeøya (see Fig. 2), at the sill level at station 1 and at the bottom at the sill (station 2), (c) BSW volume transport $Q$ across the sill and wind stress component from $67.5^{\circ} \mathrm{T}$.

several events, consistent with Chapman (1999) who found that typical ocean adjustment scale is typically 10-20 days depending on the geometry and forcing of the polynya.

The ability of the wind forcing to drive out dense water from behind the sill, visible from strong overflow events not connected to salinity maxima at the sill (Fig. 11) and the dampening of high salinity events in the basin suggest that the dense water production at the polynya acts rather as a background mechanism: the gradual salinity increase in the Storfjorden basin provides the brine-enriched shelf water, which fills up the basin to the sill level and is then flowing over the sill, mainly in the form of wind-driven pulses.

Possible excessive mixing in the model could dampen the salinity signal of a polynya event and hinder the detection of propagation from polynya to the sill. The mixing scheme used in this study is state-of-the-art, but MellorYamada schemes typically leads to overly strong mixing. For instance, when evaluated against Red Sea outflow observations, $k-k l$ scheme resulted in too large eddy diffusivities (Ilicak et al., 2008). Furthermore, the horizontal resolution $(2 \mathrm{~km})$ is likely too coarse to properly resolve the dense flow from the polynya area to the Storfjorden basin, due to the complex bathymetry in the region (Skogseth et al., 2008).

\subsection{Overflow width and height at the sill, and their in- fluence on transport estimates from measurements}

In this section, the regional ocean model results are used to test assumptions commonly made when interpreting field data of the Storfjorden overflow. We use the model data only, and calculate the overflow volume transport using various assumptions including identical methods applied to observations from a single mooring. The width of the overflow 


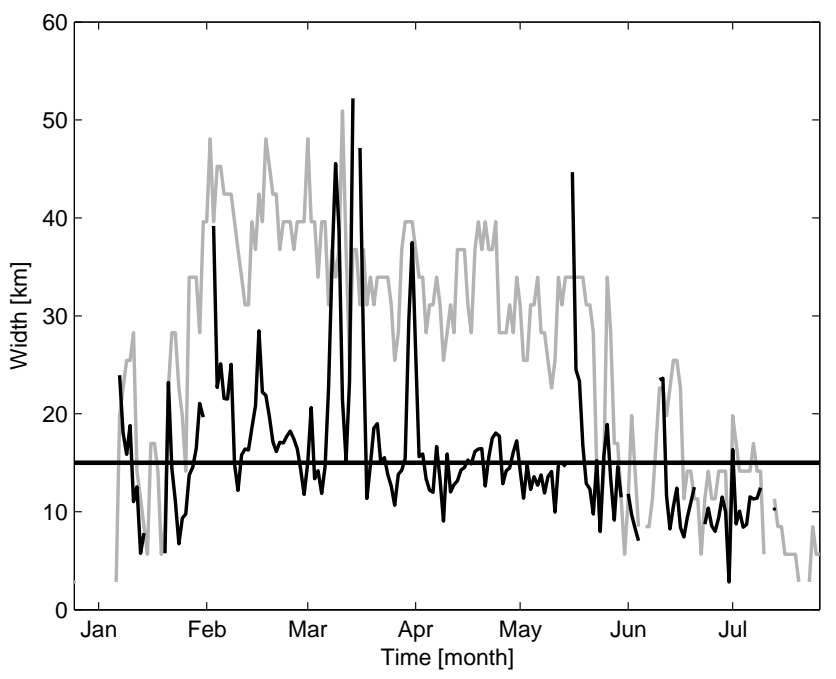

Fig. 12. Time series of overflow width $w$ (grey) and corresponding overflow width $w_{\text {corr }}$ (black) with respect to station profiles at the sill. The horizontal line denotes the constant overflow width used in Geyer et al. (2009).

plume is a source of large uncertainty in estimating volume transport from moored observations (Schauer, 1995; Schauer and Fahrbach, 1999; Geyer et al., 2009). Typically a constant width of $15 \mathrm{~km}$ is assumed. The model results show that the overflow plume width at the sill crest can vary substantially exceeding $40 \mathrm{~km}$ during the overflow maximum in February and early March, thus covering two thirds of the width of the sill and the adjacent slopes (Fig. 12). The episodic wide plume events receive support from the recent observation of BSW over the the easternmost part of the sill (Skogseth et al., 2008). However, if we define the corresponding width, $w_{\text {corr }}$, that is required to obtain the (modeled) overflow volume transport

$Q=w_{\mathrm{corr}} \int_{z=-H}^{z=0} u_{\mathrm{out}} d z$

from (modeled) profiles of outflow velocity of BSW $u_{\text {out }}$ at the location corresponding to the sill mooring (station 2), the variability is considerably smaller. Except for a few events when the overflow misses the station, the corresponding overflow width is about $15 \mathrm{~km}$ throughout the overflow season (Fig. 12), in agreement with the width assumed in Geyer et al. (2009) and earlier studies (Schauer, 1995; Schauer and Fahrbach, 1999).

The extent of the brine-enriched shelf water follows mainly the temperature distribution at the sill (Sect. 3), but cannot be delineated using the velocity distribution. Due to the lack of temperature profiles at the sill, Geyer et al. (2009) estimated the vertical extent of the overflow from velocity profiles. Our model results allow us to assess any systematic errors in the corresponding overflow flux calculations. Figure 13 a compares the modeled overflow height at station 2
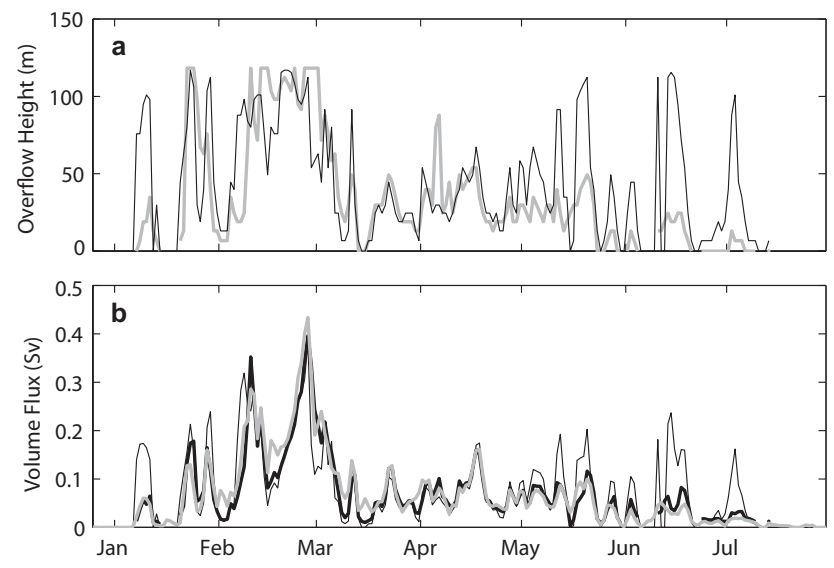

Fig. 13. Upper panel: comparison of overflow height calculated from velocity profiles following the method detailed in Geyer et al. (2009) (black) with overflow height directly determined by velocity profiles and water mass properties (grey). Lower panel: comparison of overflow volume flux estimates from determined using overflow height estimate and constant overflow width of $15 \mathrm{~km}$ (thin black line) and correct overflow height and constant overflow width of $15 \mathrm{~km}$ (thick black line), respectively, with directly determined overflow volume transport (grey).

calculated directly from water-mass characteristics and velocity profiles to that calculated by velocity profiles alone, using the method laid out in Geyer et al. (2009). For the active overflow period from January to April the plume height determined from current profiles agrees reasonably well with the actual height, so that the method captures the vertical extent of the overflow correctly. For the later and weaker part of the overflow season from May to July, however, the plume thickness is substantially overestimated. The overestimation is neither connected to bottom velocities nor temperatures, but rather caused by the outflow of warmer water at intermediate layers.

The effects of the plume width and height estimates on the overflow transport are shown in Fig. 13b. The overflow volume transport is calculated in three different ways from model data. The "actual" overflow volume transport $\left(Q_{1}\right)$ is calculated by integrating the total outflow of BSW across the sill. Secondly, velocity and hydrographic $(T / S)$ profiles are extracted at station 2 (the mooring location), and the volume transport $\left(Q_{2}\right)$ is calculated using the outflow over the thickness of the BSW identified by $T / S$ properties, assuming 15 $\mathrm{km}$ width. Finally, the volume transport $\left(Q_{3}\right)$ is calculated using the outflow over the thickness identified by the outflow velocity profiles and assuming $15 \mathrm{~km}$ width. The calculation of $Q_{3}$ is identical to that from current profile observations from the mooring. Overflow volume transport $Q_{2}$ is acceptably accurate since the constant width of $15 \mathrm{~km}$ is a reasonable approximation and the plume thickness is properly inferred. The overflow transport $Q_{3}$ is correct for a large part of the overflow season, but overestimates the actual transport 
for the intermittent overflow periods from May to July. Averaged over the 202 days overflow season, overflow volume flux $Q_{1}=0.071 \pm 0.076 \mathrm{~Sv}$ ( \pm one standard deviation). Current profile based estimate captures both the mean and the variability resulting in $Q_{3}=0.077 \pm 0.078 \mathrm{~Sv}$. $Q_{3}$ explains $58 \%$ of the variance of $Q_{1}$ and on the average agrees to within $10 \%$ of $Q_{1}$ with a standard error of $0.054 \mathrm{~Sv}$.

\section{Conclusions}

Results from the first realistic simulation of the Storfjorden region are presented. The regional ocean model system (ROMS) with a fully coupled dynamic and thermodynamic sea-ice model realistically reproduces the salient features of one freezing and overflow season in Storfjorden. Results are consistent with previously reported circulation patterns and the observations from both the polynya and the overflow region.

The overflow volume transport of brine-enriched shelf water (BSW) at the sill is strongly connected to wind forcing. Wind from east-northeast enhances surface inflow across Storfjordbanken between the sill and Edgeøya and a corresponding return flow at depth in the western part of the sill, which strengthens the dense overflow. While the Storfjorden polynya opens in response to easterly winds, causing ice formation and BSW production, the density excess cannot be traced into the basin as a pulse but instead a gradual increase in local salinity and density is seen. The variability of the dense overflow at the sill crest is found to be determined largely by the wind stress. The response of the fjord and hence the overflow to isolated polynya events is at longer time scales (about 25 days), which integrates the buoyancy forcing induced by the polynya over several polynya events. This result suggests that reasonable estimates of ocean response can be obtained from coarse observations of satellite images and surface forcing at steady state or at coarse temporal resolution.

The overflow plume width at the sill crest varies, occasionally exceeding $40 \mathrm{~km}$ (entire extent of the sill). However, the common constant overflow width assumption used to estimate volume transports from point measurements is shown to hold rather well. Detailed analysis of the model data suggests that, assuming the modeled total overflow transport as benchmark value, the volume flux of the BSW plume can be monitored by a single current profiler at the sill crest capturing $58 \%$ of the variability and accurate to within $10 \%$ when averaged over the overflow duration.

Acknowledgements. The authors want to thank T. Eldevik for his helpful comments on the manuscript and W. P. Budgell for his support with model runs. This work is funded by the Research Council of Norway, through Bipolar Atlantic Thermohaline Circulation (BIAC) project. This is publication no. A267 from the Bjerknes Center of Climate Research.

Edited by: T. Fichefet

\section{References}

Aagaard, K., Coachman, L. K., and Carmack, E.: On the halocline of the Arctic Ocean, Deep-Sea Res., 28A, 529-545, 1981.

Aagaard, K., Swift, J. H., and Carmack, E.: Thermohaline circulation in the Arctic Mediterranean Seas, J. Geophys. Res., 90, 4833-4846, 1985.

Anderson, L. G., Falck, E., Jones, E. P., Jutterström, S., and Swift, J. H.: Enhanced uptake of atmospheric $\mathrm{CO} 2$ during freezing of seawater: A field study in Storfjorden, Svalbard, J. Geophys. Res., 109, C06004, doi:10.1029/2003JC002120, 2004.

Arrigo, K. R., van Dijken, G., and Pabi, S.: Impact of a shrinking Arctic ice cover on marine primary production, Geophys. Res. Lett., 35, L19603, doi:10.1029/2008GL035028, 2008.

Bauch, D. P., Schlosser, P., and Rairbanks, R.: Freshwater balance and the sources of deep water and bottom waters in the Arctic Ocean inferred from the distribution of $\mathrm{H}_{2}{ }^{18} \mathrm{O}$, Prog. Oceanogr., 35, 53-80, 1995.

Beckman, A. and Haidvogel, D. B.: Numerical simulation of flow around a tall isolated seamount. Part I: Problem formulation and model accuracy, J. Phys. Oceanogr., 23, 1736-1753, 1993.

Budgell, W. P.: Numerical simulation of ice-ocean variability in the Barents Sea region towards dynamic downscaling, Ocean Dynam., 55, 370-387, 2005.

Carmack, E. and Chapman, D. C.: Wind-driven shelf/basin exchange on an Arctic shelf: The joint roles of ice cover extent and shelf-break bathymetry, Geophys. Res. Lett., 30, 1778, doi:10.1029/2003GL017526, 2003.

Chapman, D. C.: Dense water formation beneath a time-dependant coastal polynya, J. Phys. Oceanogr., 29, 807-820, 1999.

Engedahl, H.: Use of the flow relaxation scheme in a threedimensional baroclinic model with realistic topography, Tellus, 47A, 365-382, 2009.

Ersdal, E. A.: On the tidal forcing of the Storfjorden polynya, M. Sc., Univ. of Bergen, 2009.

Fer, I., Skogseth, R., Haugan, P. M., and Jaccard, P.: Observations of the Storfjorden outflow, Deep-Sea Res. I, 50, 1283-1303, 2003.

Fer, I., Skogseth, R., and Haugan, P. M.: Mixing of the Storfjorden overflow (Svalbard Archipelago) inferred from density overturns, J. Geophys. Res., 109, C01005, doi:10.1029/2003JC001968, 2004.

Fer, I. and Ådlandsvik, B.: Descent and mixing of the overflow plume from Storfjord in Svalbard: an idealized numerical model study, Ocean Sci., 4, 115-132, 2008, http://www.ocean-sci.net/4/115/2008/.

Geyer, F., I. Fer and T. Eldevik (2009): Dense overflow from an Arctic fjord: Mean seasonal cycle, variability and wind influence, Cont. Shelf Res., 29, 2110-2121, 2009.

Häkkinen, S. and Mellor, G. L.: Modeling the seasonal variability of a coupled Arctic ice-ocean system, J. Geophys. Res., 97, 20285 20403, 1992.

Hunke, E. C. and Dukowicz, J. K.: An elastic-viscous-plastic model for sea ice dynamics, J. Phys. Oceanogr., 27, 1849-1867, 1997.

Hunke, E. C.: Viscous-plastic sea ice dynamics with the EVP model: linearization issues, J. Comp. Phys., 170, 18-38, 2001.

Ilicak, M., Özgökmen, T. M., Peters, H., Baumert, H. Z., and Iskandarani, M.: Performance of two-equation turbulence closures in three-dimensional simulations of the Red Sea overflow, Ocean Modell., 24, 122-139, 2008. 
Jungclaus, J. H., Backhaus, J. O., and Fohrmann, H.: Outflow of dense waters from the Storfjord at Svalbard: a numerical model study, J. Geophys. Res., 100, 24719-24728, 1995.

Kalnay, E., Kanamitsu, M., Kistler, R., Collins, W., Deaven, D., Gandin, L., Iredell, M., Saha, S., White, G., Woollen, J., Zhu, Y., Chelliah, M., Ebisuzaki, W., Higgins, W., Janowiak, J., Mo, K. C., Ropelewski, C., Wang, J., Leetmaa, A., Reynolds, R., Jenne, R., and Joseph, D. (1996): The NCEP/NCAR 40-year reanalysis project, B. Am. Meteorol. Soc., 77, 437-471, 1996.

Loeng, H.: Features of the physical oceanographic conditions in the Barents Sea, Pol. Res., 10, 5-18, 1991.

Mellor, G. L. and Yamada, T.: Development of a turbulent closure model for geophysical fluid problems, Rev. Geophys. Space Phys., 20, 851-875, 1982.

Mellor, G. L. and Kantha, L.: An ice-ocean coupled model, J. Geophys. Res., 94, 10937-10954, 1989.

Perovich, D. K., Richter-Menge, J. A., Jones, K. F., and Light, B.: Sunlight, water, and ice: Extreme Arctic sea ice melt during the summer of 2007, Geophys. Res. Lett., 35, L11501, doi:10.1029/2008g1034007, 2008.

Quadfasel, D., Rudels, B., and Kurz, K.: Outflow of dense water from a Svalbard fjord into the Fram Strait, Deep-Sea Res., 35, 1143-1150, 1988.

Rudels, B. and Quadfasel, D.: Convection and deep water formation in the Arctic Ocean-Greenland Sea system, J. Mar. Syst., 2, 435450, 1991.

Schauer, U.: The release of brine-enriched shelf water from the Storfjord into the Norwegian Sea, J. Geophys. Res., 100, 1601516028, 1995.

Schauer, U. and Fahrbach, E.: A dense bottom water plume in the western Barents Sea: downstream modification and interannual variability, Deep-Sea Res. I, 46, 2095-2108, 1999.

Shchepetkin, A. F. and McWilliams, J. C.: The regional oceanic modeling system (ROMS): a split-explicit, free-surface, topography-following-coordinate oceanic model, Ocean Model., 9, 347-404, 2005.

Skogseth, R., Fer, I., and Haugan, P. M.: Dense-water production and overflow from an Arctic coastal polynya in Storfjorden, in: The Nordic Seas: An Integrated Perspective, Geophysical Monograph Series, vol. 158, edited by: Drange, H., Dokken, T., Furevik, T., Gerdes, R., and Berger, W., AGU, Washington, DC, 73$88,2005 \mathrm{a}$.
Skogseth, R., Haugan, P. M., and Jakobsson, M.: Watermass transformations in Storfjorden, Cont. Shelf Res., 25, 667-695, 2005 b.

Skogseth, R., Sandvik, A. D., and Asplin, L.: Wind and tidal forcing on the meso-scale cirulation in Storfjorden, Svalbard, Cont. Shelf Res., 27, 208-227, 2007.

Skogseth, R., Smedsrud, L. H., Nilsen, F., and Fer, I.: Observations of hydrography and downflow of brine-enriched shelf water in the Storfjorden polynya, Svalbard, J. Geophys. Res., 113, C08049, doi:10.1029/2007JC004452, 2008.

Skogseth, R., Nilsen, F., and Smedsrud, L. H.: Supercooled water in an Arctic polynya: observations and modeling, J. Glaciol., 55(189), 43-52, 2009.

Smedsrud, L. H., Budgell, W. P., Jenkins, A. D., and Ådlandsvik, B.: Fine-scale sea-ice modelling of the Storfjorden polynya, Ann. Glaciol., 44, 73-79, 2006.

Song, T. and Haidvogel, D.: A semi-explicit ocean circulation model using a generalized topography-following coordinate system, J. Comput. Phys., 115, 228-244, 1994.

Warner, J. C. and Geyer, W. R. (2005): Numerical modelling of an estuary: a comprehensive skill assessment, J. Geophys. Res., 110, C05001, doi:10.1029/2004JC002691, 2005.

Warner, J. C., Sherwood, C. R., Arango, H. G., and Signell, R. P.: Performance of four turbulence closure models implemented using a generic length scale method, Ocean Model., 8, 81-113, 2005.

Wessel, P. and Smith, W. H. F.: A global self-consistent, hierarchical, high-resolution shoreline database, J. Geophys. Res., 101, 8741-8743, 1996.

Winsor, P. and Björk, G.: Polynya activity in the Arctic Ocean from 1958-1997, J. Geophys. Res., 105, 8789-8803, 2000.

World Meteorological Organization (WMO): WMO sea-ice nomenclature, Geneva, World Meteorological Organization (WMONo. 259, TP. 145 ed.), 1970. 